\title{
Original article (short paper) \\ Guided play and free play in an enriched environment: Impact on motor development
}

\author{
Míriam Stock Palma \\ Federal University of Rio Grande do Sul, Brazil \\ Beatriz Oliveira Pereira \\ University of Minho, Portugal \\ Nadia Cristina Valentini \\ Federal University of Rio Grande do Sul, Brazil
}

\begin{abstract}
The purpose of this study was to investigate the effects of guided play and free play in an enriched environment intervention programs using motor skill development in kindergarten children. Seventy-one children attending kindergarten classes were assigned to two experimental groups and one control group. Participants performed the Test of Gross Motor Development-2 before and after the intervention period. Results revealed that both boys and girls in the guided play group showed motor skill improvement, whereas no changes were observed in motor development in the boys and girls assigned to the free play in enriched environment group, nor in those in the control group. These findings indicate that the teacher's role in the guided play intervention was crucial to help preschool children to improve their performance.
\end{abstract}

Keywords: preschool childhood, motor skill development, physical education

Resumo - “Jogo com orientação e jogo livre em contexto enriquecido: Impacto no desenvolvimento motor.” O objetivo deste estudo foi investigar os efeitos das intervenções jogo com orientação e jogo livre em ambiente enriquecido sobre o desenvolvimento de habilidades motoras de crianças pré-escolares. Participaram da investigação 71 crianças matriculadas em turmas de jardim de infância, distribuídas em dois grupos experimentais e um grupo controle. Foi aplicado aos participantes o Test of Gross Motor Development - Second Edition, antes e após o período interventivo. Os resultados evidenciaram que os meninos e meninas do grupo jogo com orientação apresentaram ganhos em habilidades motoras, ao passo que mudanças não foram observadas nos meninos e meninas que constituíram o grupo jogo livre em ambiente enriquecido, nem nos do grupo controle. Esses achados indicam que o papel do professor no grupo jogo com orientação foi determinante para a melhora de desempenho das crianças pré-escolares.

Palavras-chave: infância pré-escolar, desenvolvimento de habilidades motoras, educação física

Resumen - “Juego con orientación y juego libre en contexto enriquecido: efectos sobre el desarrollo motor." El objetivo de este estudio fue investigar los efectos de las intervenciones juego con orientación y juego libre en contexto enriquecido sobre el desarrollo de habilidades motoras de niños preescolares. Participaron en la investigación 71 niños matriculados en clases del parvulario, distribuidos en dos grupos experimentales y un grupo control. A los participantes se les aplicó el Test of Gross Motor Development - Second Edition, antes y después del periodo de intervención. Los resultados indicaron que los niños y niñas en el grupo juego con orientación mostraron ganancias en las habilidades motoras, mientras que no se observaron cambios en los niños y niñas que constituyeron el grupo juego libre en contexto enriquecido, ni tampoco en aquéllos en el grupo control. Esos hallazgos indican que el papel del maestro en el grupo juego con orientación fue determinante para la mejora del desempeño de los niños preescolares.

Palabras clave: niñez preescolar, desarrollo de habilidades motoras, educación física 


\section{Introduction}

During the early education years, children are actively involved in exploring the environment and practicing their motor skills in order to adapt to the challenges imposed by the surrounding environment. Although free exploration of movement is essential to growth and development, it is well known that this achievement is determined by opportunities provided in the environment by the adults responsible for their education (Gabbard, 2011; Ramey \& Ramey, 1994).

The experiences in diverse tasks and free play in the early years are considered fundamental for the learning of more sophisticated motor skills that will be used throughout childhood and even later in the life cycle, such as sports and dance skills (Gabbard, 2011; Haywood \& Getchell, 2009; Payne \& Isaacs, 2008; Seefeldt \& Haubenstricker, 1982). There is as association between the quality of these early experiences and an active life style (Gabbard, 2011). Although maturation processes determines developmental changes, individuals' experiences are cumulative over the life cycle and their development is affected by the quality of challenges they face with. Although age is not necessarily a determinant factor in motor development, in the first years of life age is associated with the later. As a child grows, other factors play a more important role on his or her motor development (Barela, 2013; Gallahue, Ozmun, \& Goodway, 2011). Therefore, the complexity of motor behavior could be illustrated in terms of how individual constraints, socio-cultural constraints in the environment, as well as specific biomechanical and physical demands of each motor task an individual endures, all affect individual lives (Newell, 1986).

The variety of motor experiences in early age combined with a variety of equipment and safe facilities, as well as the mediation of a teacher who acknowledges and respects the children's characteristics and needs, may represent a unique opportunity for facilitating development and learning (Goodway \& Branta, 2003; Sanders, 2002; Siedentop \& Tannehill, 2000). It is also important to consider the pleasure children in general show when performing movement activities, and their motivation for learning in programs that focus on the acquisition and refinement of motor skills (Valentini \& Rudisill, 2004a, 2004b). Accordingly, Barela (2013) draws attention to the fact that the acquisition and refinement of these skills are a process that occurs over years and that the development of motor proficiency should be emphasized by specific physical activity programs and by regular physical education even early in life, such as in the kindergarten and elementary school years.

Several studies have shown important and positive results from motor skill intervention during early childhood (Connor -Kuntz \& Dummer, 1996; Goodway \& Branta, 2003; Goodway, Crowe, \& Ward, 2003; Lemos, Avigo, \& Barela, 2012; Marshall \& Bouffard, 1997; Palma, Camargo, \& Pontes, 2012; Rodrigues, Avigo, Leite, Bussolin, \& Barela, 2013; Valentini \& Rudisill, 2004a, 2004b). Goodway et al. (2003) investigated two groups of American kindergarten children identified as being at risk for motor development delay. One group participated in a specific program, the Successful Kinesthetic Instruction for Preschoolers (SKIP), twice a week, for 9 weeks; the other group participated in a program that implemented free play without any specific fundamental motor skill instruction. In another study, Valentini and Rudisill (2004b) investigated the benefits of an inclusive motor skill intervention implemented during 12 weeks for 104 Brazilian children (ages from 5 to 10) with and without disabilities. Both studies indicated that the intervention groups positively changed locomotor and object-control skills over the intervention period. Also, in both studies, the control groups, although continuously practicing motor tasks in free play, did not demonstrate significant changes over the intervention period.

Research conducted by Lemos et al. (2012) compared the development of motor skills of fifty healthy children, ages 5 to 6 from a public school in Guarulhos city, in São Paulo. Twenty-five children were assigned to a physical education activity group (PE) taught by a physical education specialist who used cooperative games and fundamental motor skills activities in an enjoyable and playful environment. Twenty-five children were assigned to a recreational activity group (RE), in which they were exposed to activities typically developed in the school playground (i.e., children played by themselves under the supervision of the classroom teacher). Results revealed that both groups of children showed similar motor skill development before enrollment. After the period of engagement in the respective activities program, PE children showed better motor skill development than RE children.

Comparing different teaching approaches, Valentini and Rudisill (2004a) investigated the impact of a mastery climate intervention (emphasizing high autonomy for students) and a direct instruction intervention (emphasizing the teacher's role in the decision-making process and low autonomy opportunities for students) on children's motor skill development. Kindergarten children participated in this study and results showed that both interventions promoted significant gains in locomotor and object-control skills. However, participants in the high autonomy approach group showed better benefits from the environmental strategies of mastery intervention, demonstrating superior locomotor skill performance after the intervention.

In general, research shows that different teaching approaches implementing high to low-autonomy strategies are beneficial to learners - whether typically developing children or children with delays or disabilities are observed - if the quality of practice is warranted to them (Goodway \& Branta, 2003; Goodway et al., 2003; Goodway \& Rudisil, 1997; Valentini \& Rudisill, 2004a, 2004b). In these intervention studies, the great variety of tasks seems to ensure the quality of practice (Gallahue \& Donnelly, 2003; National Association for Sport and Physical Education [NASPE], 2000); opportunities for children to participate in moderate to intense efforts without waiting in lines (Rink, 2003; Sanders, 2002); instruction, modeling, and suitable feedback (Weiss \& Gill, 2005); as well as direct and indirect teaching strategies (NASPE, 2000; Sanders, 2002). Such results vary according to the content to be developed, the children's previous experience with the skills to be taught, and their motivation to learn (Graham, Holt-Hale, \& Parker, 2007; Siedentop $\&$ Tannehill, 2000). Additionally, the quality of practice is dependent upon a safe environment and appropriate equipment so that all children can experience success in their motor attempts 
(Graham, 2008; Sanders, 2002). Promoting the equity between genders and children with different levels of ability is also essential in an educational program and, therefore, teachers have to deal with these specific issues in order to provide appropriate experiences to all (Kirk, 2003; Lee, 2002). The Council on Physical Education for Children [COPEC] (1992) suggests that teachers use pedagogical strategies appropriate to each child's level of development. Therefore, adaptations in the tasks and in the learning environment are crucial to maximize learning.

Sacha and Russ (2006) call attention to the fact that, although studies that use different teaching approaches in physical education intervention have shown positive results for kindergarten children, more consistent studies focusing on the role of free play in motor skill development in the early years are in demand. These authors also emphasized the importance of teaching playful dances to children.

The debate about physical education curricula for young children is still growing. Some questions are raised about the use of free play, or free approaches with exploration methods or direct methods (NASPE, 2000; Sanders, 2002). Smith (1993) points out that, for several educators in the Western Europe, a curriculum based on free play is the ideal way for preschool students. However, several researchers agree that only free play and exploration methods are not powerful enough to help children to achieve their full potential. Therefore, authors such as Graham et al. (2007), Gallahue \& Donnelly (2003), NASPE (2000) and Sanders (2002) advise that the use of different teaching methods and learning strategies should be in combination. In this perspective, the present study focuses on the quality of physical education programs for young children. Such programs should include a combination of different teaching strategies to meet both (1) the needs of children to play and (2) the intervention of a teacher to maximize their potential through proper instruction.

Several studies have portrayed gender differences in motor competency in different age groups, often favoring boys from the age of five up to adolescence. During the infancy years, boys are more active than girls (Booth et al., 1999; Okely \& Booth, 2004) and improve faster their fundamental motor skill performance, showing higher levels of proficiency in throwing, catching, kicking, dribbling, striking, and underhand rolling (Beurden, Zask, Barnett, \& Dietrich, 2002; Booth et al., 1999; Goodway \& Rudisill, 1997; Hume et al., 2008; Valentini \& Rudisill, 2004a; 2004b). In studies with kindergarten children with motor delays, the same tendency is observed. Researchers have reported the superiority of boys over girls in performing all object-control skills, and similar patterns of development between boys and girls for locomotor skills (Goodway et al., 2003; Goodway \& Rudisill, 1997; Valentini \& Rudisill, 2004a).

These differences have been attributed to the fact that greater opportunities for practice are offered to boys due to a cultural understanding of their need for movement activity. Kirk (2003) suggests that girls have fewer opportunities to participate in high quality physical education programs, and Weiss and Gill (2005) sustain that physical education programs often fail in helping girls to achieve more sophisticated motor performance, as well as in providing them with attractive activities.

On the other hand, Ojala and Talts (2007) showed that kindergarten girls surpass boys' performance in nine areas of learning: learning to learn skills, social skills, language and interaction, mathematics, ethics, science and environment, health, physical and motor development, and art and culture. A concern is shared in relation to the fewer opportunities provided for children, specifically for girls, to practice motor skills. Authors advocate the need for interventions to create equal opportunities for boys and girls, develop strategies for girls to be physically more active, and strengthen girls' believes and perceptions of motor skill competence (Lee, 2002; Valentini \& Rudisill, 2004a; 2004b).

Therefore, the purpose of this study was to verify the influence of motor intervention programs, free play in enriched environment and guided play, on the development of fundamental motor skills in kindergarten boys and girls. We hypothesize that the children in the guided play group will demonstrate significantly superior motor skill development and higher scores in motor skill performance (locomotor, object-control, gross motor quotient) after the intervention than the children in the free play in enriched environment and control groups. Significant changes in motor performance over time in children in the free play in enriched environment and control groups are not expected.

Regarding the gender issue, we hypothesize that (1) overall boys will demonstrate a superior motor performance compared to girls; (2) girls and boys in the guided play group will show a similar pattern of development after the intervention period; and (3) boys and girls in the free play in enriched environment and control groups will not show positive and significant changes over time.

\section{Method}

\section{Participants}

A total of 71 children (40 boys and 31 girls), ages 5-6 years $(M=5.58 ; S D=0.27)$, attending kindergarten classes in an European public school participated in the study. These children lived in a small town or in peripheral rural areas, and all were from middle-class families. Children enrolled in three intact kindergarten classes were randomly assigned to two experimental groups and one control group. Participants in the experimental groups attended two distinct movement programs: guided play and free play in enriched environment. Thus, 22 children (11 boys and 11 girls) took part in the guided play program, 24 (15 boys and 9 girls) took part in the free play in enriched environment program, and 25 (14 boys and 11 girls) were assigned to the control group.

Informed consent was obtained from the custodial caregiver(s) of each child participating in the study. Verbal consent was obtained from each child by asking the child if he or she would like to participate in a movement program.

\section{Instrumentation}

The Test of Gross Motor Development - Second Edition (TGMD-2) (Ulrich, 2000) was used to assess the participants' 
motor skill performance. The TGMD-2 provides norm-referenced and criterion-referenced data, and evaluates 12 gross motor skills of children ages 3 to 10 . The TGMD-2 consists of two subtests: locomotor and object-control. The locomotor subtest comprises the following six skills: run, gallop, hop, leap, horizontal jump, and slide; and the object-control subtest comprises six other skills: striking a stationary ball, stationary dribble, catch, kick, overhand throw and underhand roll.

The test includes a raw score, a standard score, and a percentile for each subtest (locomotor and object-control), besides the gross motor quotient. Standard scores and the gross motor quotient were used in this study. The standard scores take into consideration the child's age (ranging from 1 to 20 points for each subtest); and the gross motor quotient (ranging from 46 to 160 points) is considered by the author the best representation of a child's overall performance (Ulrich, 2000).

\section{Procedures}

All the 71 children were assessed using the TGMD-2, immediately before and after the implementation of the movement programs. The standardized test protocol suggested by the author of the test (Ulrich, 2000) was used to administer the TGMD-2. Test administration took approximately 15-20 minutes per child. Each child was videotaped performing the TGMD-2. Two digital cameras were used: one for a frontal view, which enabled the first analysis of the children's movement performance, and the other for a side view, used to confirm the analysis of the first camera. The researcher and two independent raters were responsible for analyzing the TGMD-2 performances. The researcher had a long field experience as a teacher and was trained for two years in the use of TGMD-2. The independent raters were also trained in the use of the instrument for two years. The two raters did not participate at any stage of the intervention, they had no knowledge of the time they were evaluating (pre-test or post-test), and they did not know to which group each child belonged (play with orientation, free play in enriched environment or control groups). Approximately one hour was the time necessary to analyze each child's performance from the videotapes.

In this study, the inter-rater reliability coefficients for the TGMD-2 were very high both for pre-test ( 0.91 for the locomotor subtest; 0.94 for the object-control subtest; and 0.91 for gross motor quotient) and post-test ( 0.95 for the locomotor subtest; 0.94 for the object-control subtest; and 0.96 for gross motor quotient). Berry, Poortinga, Segall, and Dasen (1992) state that an alpha superior to 0.9 express a very good internal consistency. Besides, these results are comparable to the reliability coefficients in Ulrich (2000), which range between 0.84 and 0.96 .

\section{Implementation of the movement programs}

Each movement program consisted of 32 sessions during an 8-week period, with four meetings a week. Each session lasted 45 minutes. Appropriate equipment, facilities and supervision were provided for both groups, although the two approaches have differed in relation to instruction and learning strategies.
The guided play program included strategies as free play, oriented play and fundamental motor skill activities conducted by the researcher, who was assisted by two physical education teachers in all the 32 sessions. Throughout the intervention period, the sessions were carefully planned, implemented and evaluated, making use of daily meetings between the researcher and the physical education teachers for the development of objectives, choice of content, defining methods to be used, selection and placement of materials into the class environment, as well as for the ongoing assessment of the program. In accordance with findings by Gabbard (2011) and Gallahue and Donnelly (2003), it is crucial that, in quality movement programs, young children are allowed to experience a wide and varied repertoire of motor skills. In this current program children experienced a large number of stability skills (i.e., that require balance, such as rotating, pushing, pulling, stretching, etc.), locomotor skills (which allow the projection of the body from one point to another in space, such as walking, running, jumping, galloping, etc.) and manipulative skills (for to control objects with their hands, feet or other body parts, such as dribbling, kicking, throwing, catching, etc.) in a variety of situations. Distinct learning strategies were used at different moments of the sessions, taking into consideration the objectives of each session, the type of activities being proposed, the children's previous experiences in each activity, and their motivation to participate. Using a combination of directive and non-directive approaches of teaching, a wide range of motor activities was provided for all children in order to optimize their participation. The challenges in each task were adjusted to each child's individual needs. During the practice instruction, modeling, and verbal feedback were provided helping children to focus their attention to important motor aspects of the movement. The lessons were conducted in a large indoor court, with a great diversity of novel equipment. Equal opportunities for practice were ensured to girls and boys, and to children with different levels of abilities. Children were constantly encouraged by the teacher to move, explore and challenge themselves.

The free play in enriched environment program was implemented to the other experimental group. For this group, the practice took place in the same space, using the same equipment as the children in the guided play program. However, in this intervention approach of teaching, children explored and used the equipment, and changed games and activities as they wished, without any suggestion or orientation from the researcher or the physical education teachers, throughout the activities.

Participants in the control group did not take part in any intervention related to investigation between pre- and post-test. In compliance with ethical protocol for the investigation in human beings, after the post-test, a physical education program similar to the Guided play program was administered to participants in the control group.

\section{Data analyses}

Data were analyzed using nonparametric tests since the Kolmogorov-Smirnov test showed a non-normal distribution. The Kruskal-Wallis test was conducted to compare the groups. To follow-up significant differences between the groups, the 
Guided play and free play

Table 1. Pre- and post-test locomotor and object-control raw scores and gross motor quotient by group.

\begin{tabular}{|c|c|c|c|c|c|}
\hline \multirow[t]{2}{*}{ Variable } & \multirow[t]{2}{*}{ Group } & \multicolumn{2}{|r|}{ Pre-test } & \multicolumn{2}{|c|}{ Post-test } \\
\hline & & $\mathrm{md}$ & $\mathrm{P}_{25}-\mathrm{P}_{75}$ & $\mathrm{md}$ & $\mathrm{P}_{25}-\mathrm{P}_{75}$ \\
\hline \multirow{3}{*}{$\begin{array}{l}\text { Locomotor } \\
\text { subtest }\end{array}$} & Guided play & 6.00 & $5.75-7.00$ & 7.00 & $7.00-8.00$ \\
\hline & $\begin{array}{l}\text { Free play in enriched } \\
\text { environment }\end{array}$ & 7.00 & $5.25-8.00$ & 6.00 & $6.00-8.00$ \\
\hline & Control group & 6.00 & $4.50-8.00$ & 6.00 & $5.00-8.00$ \\
\hline \multirow{3}{*}{$\begin{array}{l}\text { Object-Control } \\
\text { subtest }\end{array}$} & Guided play & 7.00 & $5.75-8.00$ & 9.00 & $7.75-10.25$ \\
\hline & $\begin{array}{l}\text { Free play in enriched } \\
\text { environment }\end{array}$ & 7.00 & $7.00-9.00$ & 7.50 & $7.00-9.00$ \\
\hline & Control group & 8.00 & $6.50-9.50$ & 7.00 & $6.00-9.00$ \\
\hline \multirow{3}{*}{$\begin{array}{l}\text { Gross Motor } \\
\text { Quotient }\end{array}$} & Guided play & 79.00 & $76.00-82.75$ & 89.50 & $82.00-97.00$ \\
\hline & $\begin{array}{l}\text { Free play in enriched } \\
\text { environment }\end{array}$ & 82.00 & $79.00-88.00$ & 83.50 & $79.00-88.00$ \\
\hline & Control group & 82.00 & $76.00-88.00$ & 82.00 & $73.00-88.00$ \\
\hline
\end{tabular}

Mann-Whitney test was used. Wilcoxon test was conducted to verify time main effect. In the gender comparisons, the Mann -Whitney test was used. To verify the impact of the intervention on girls and boys, the Wilcoxon test was used.

\section{Results}

\section{Motor performance}

\section{Group comparisons}

Locomotor performance: The Kruskal-Wallis test showed that, in the pre-test, no statistically significant differences ( $p=$ 0.397) among the guided play, free play in enriched environment and control groups were found for locomotor performance; however, in the post-test, significant differences were found among the groups $(p=0.042)$. The follow-up Mann-Whitney test revealed a superior performance in the post-test for the guided play group compared to the free play in enriched environment ( $p$ $=0.029)$ and control $(p=0.036)$ groups. Statistically significant differences were not found between the free play in enriched environment and control groups $(p=0.375)$.

Furthermore, the Wilcoxon test indicated significant and positive changes in performance for the guided play group ( $p=$ 0.006 ) from pre- to post-test. Meanwhile, for the free play in enriched environment $(p=0.551)$ and control $(p=0.984)$ groups, significant changes in locomotor performance over time were not observed. See Table 1 for median and coefficient interval in pre- and post-test for locomotor performance.

Object-control performance: The Kruskal-Wallis test evidenced no statistically significant differences $(p=0.159)$ among the guided play, free play in enriched environment and control groups in the pre-test; whereas in the post-test significant differences were found among the groups $(p=0.015)$. The follow-up Mann-Whitney test revealed that guided play group showed a superior performance compared to the free play in enriched environment ( $p=0.020)$ and control $(p=0.008)$ groups. Statistically significant differences were not found between the free play in enriched environment and control groups $(p=0.662)$.

The Wilcoxon test indicated significant and positive changes in performance for the guided play group $(p=0.0005)$ from pre- to post-test. Meanwhile, for the free play in enriched environment ( $p=0.886)$ and control $(p=0.196)$ groups, significant changes in object-control performance over time were not observed. See Table 1 for median and coefficient interval in pre- and post-test for object-control performance.

Gross motor performance: The Kruskal-Wallis test revealed that, in the pre-test, the difference among the three groups was not statistically significant $(p=0.191)$. However, in the post-test, the difference among groups was statistically significant $(p=0.005)$. The follow-up Mann-Whitney test revealed that the guided play group showed a superior performance when compared to the free play in enriched environment $(p=0.012)$ and control $(p=0.003)$ groups. Statistically significant differences were not found between the free play in enriched environment and control groups ( $p=0.437)$.

The Wilcoxon test indicated significant and positive changes in performance for the guided play group $(p=0.0003)$ from pre- to post-test; while, for the free play in enriched environment $(p=0.684)$ and control $(p=0.441)$ groups, significant changes for gross motor performance were not observed over time. See Table 1 for median and coefficient interval in pre- and post-test for gross motor performance.

\section{Gender comparisons}

Locomotor performance: The Mann-Whitney test results revealed that, independent of groups, girls demonstrated higher significant performance than boys $(p=0.005)$ in the pre-test. A closer look at the pre-test, using the Mann-Whitney test, indicated that girls showed higher significant performance than boys in the guided play $(p=0.002)$ and control $(p=0.025)$ groups, and performance was similar between genders in the free play 
in enriched environment ( $p=0.907)$ group. Furthermore, in the post-test, the same trend was observed; girls, independent of groups, showed higher performance than boys $(p=0.001)$. However, for the groups, the trend changed, with boys and girls showing similar performance in the guided play $(p=0.101)$ group, whereas girls demonstrated higher significant performance than boys in the free play in enriched environment ( $p=$ $0.048)$ and control $(p=0.050)$ groups.

The Wilcoxon test showed that only boys in the guided play group presented significant and positive changes in locomotor skills from pre- to post-test ( $p=0.028)$; for girls, changes over time in performance in those skills were not significant ( $p=$ $0.103)$. The results also showed that neither boys nor girls in the free play in enriched environment and control groups showed significant changes from pre-test to post-test $(p>0.05)$.

Object-control performance: The Mann-Whitney test results revealed similar performance, independent of groups, between boys and girls in the pre-test $(p=0.339)$. This test also indicated similar performance between boys and girls in the guided play $(p=0.332)$, free play in enriched environment $(p=0.599)$ and control ( $p=0.647)$ groups. In the post-test, independent of groups, performance between boys and girls was found to be similar ( $p$ $=0.747$ ) either. There were no significant differences between gender for children in the guided play $(p=0.652)$, free play in enriched environment $(p=0.379)$ and control $(p=0.202)$ groups.

The Wilcoxon test results indicated significant improvement in object-control skills for boys $(p=0.043)$ and girls $(p=0.005)$ in the guided play group from pre- to post-test. Meanwhile, neither boys nor girls in the free play in enriched environment and control groups showed statistically significant changes from pre- to post-test $(p>0.05)$.

Gross motor performance: The gross motor performance of boys and girls was not significantly different in the pre-test ( $p=$ 0.367). Boys and girls performed similarly in the three groups: guided play $(p=0.652)$, free play in enriched environment ( $p$ $=0.599)$ and control $(p=0.403)$ groups. In the post-test, there were significant differences between genders, independent of groups: girls showed better performance $(p=0.025)$ than boys regarding gross motor quotient (see Table 2). However, the Mann-Whitney test revealed that boys and girls showed similar

Table 2. Pre- and post-test locomotor and object-control raw scores and gross motor quotient by gender.

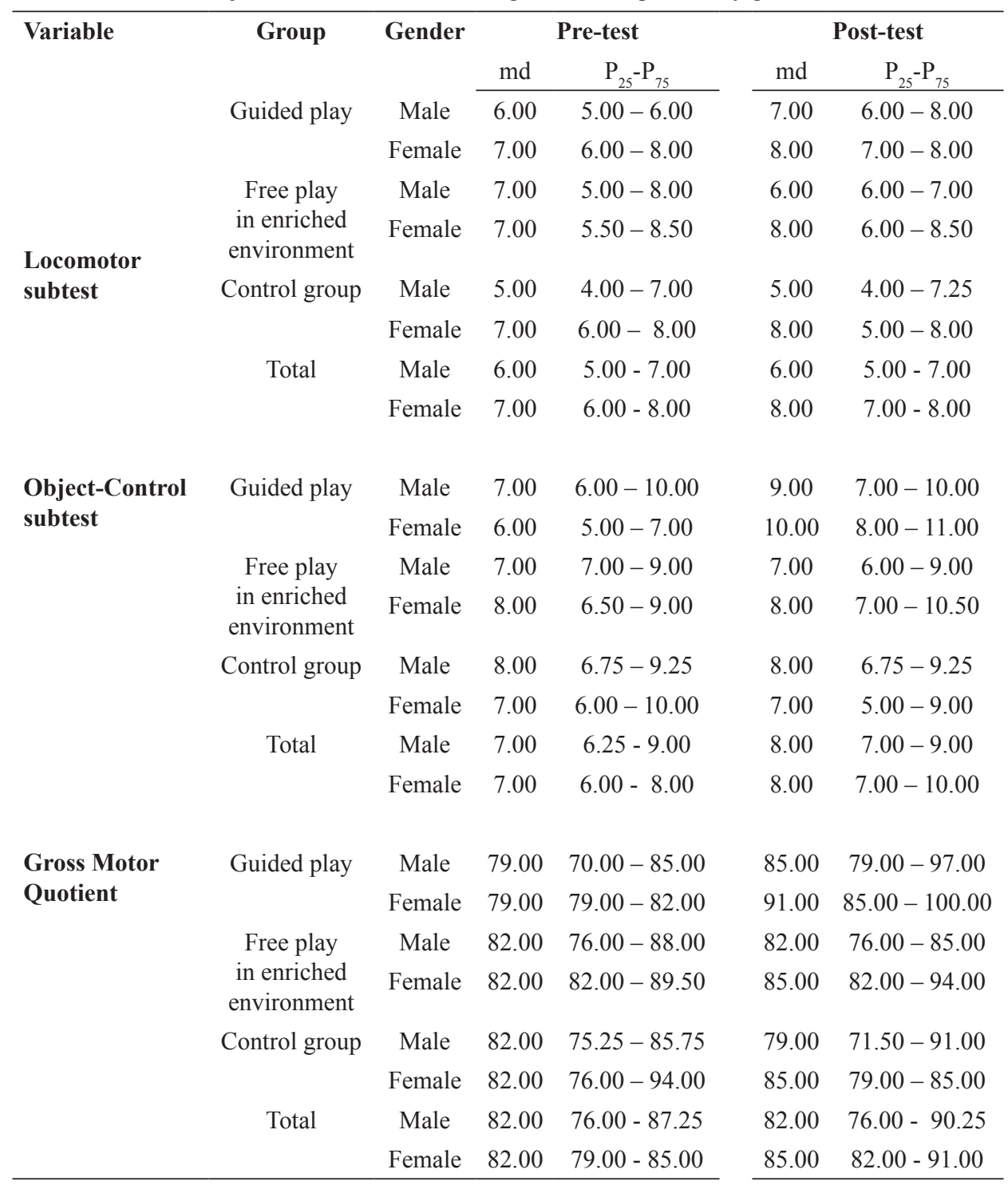


performance in the guided play $(p=0.270)$ and control $(p=$ $0.536)$ groups; only in the free play in enriched environment group, girls showed better performance than boys $(p=0.048)$.

The Wilcoxon test indicated significant improvement in gross motor quotient for boys $(p=0.018)$ and girls $(p=0.005)$ in the guided play group, while neither boys nor girls in the free play in enriched environment and control groups showed significant and positive changes over the intervention period $(p>0.05)$.

\section{Discussion}

The results of the present study revealed that, although children's motor performance was similar at the beginning of the programs, the guided play intervention was more effective in guiding children to achieve superior performance. Children in the free play in enriched environment and control groups showed no significant changes in their performance over the intervention period. These results are consistent with those from previous literature (Cotrim, Lemos, Néri Jr., \& Barela, 2011; Goodway \& Branta, 2003; Palma et al, 2012; Valentini \& Rudisill, 2004a, 2004b) that reported superior motor performance after participation in motor intervention programs for children who experienced a learning setting in which the tasks were adapted to initial levels of motor performance.

The impact of the experimental intervention over time on each group showed positive and significant changes in the fundamental motor skills restricted to the children who participated in the guided play program. Significant changes were not observed among the children in the free play in enriched environment group during the intervention, despite it providing them with a challenging environment. These results reinforce the understanding that, although maturation and opportunities for practice play an important role on children's development, encouragement and quality instruction in an ecologically sound environment are also needed in order to achieve full development (Bronfenbrenner, 1979; Gallahue et al., 2011).

Studies have already shown that children's motor performance is superior when they take part in fundamental motor skill development programs that create an atmosphere that promotes learning (Goodway \& Branta, 2003; Goodway et al., 2003; Goodway, Rudisill \& Valentini, 2002; Valentini \& Rudisill, 2004a, 2004b). These studies, as well as the present one, implemented programs that focused on children's needs and developmental characteristics, providing them with opportunities to overcome constant motor challenges and, thus, to improve their performance even over a short period of time.

Aligned with previous research, the present study demonstrated how positive changes in motor development can be achieved through planned intervention. Indeed, this was possible only in the program in which a teacher oriented the practice by guiding children to show a consistent pattern of improvement in motor performance. As suggested by Vygotsky (1980) and Bronfenbrenner (1979), teacher mediation is essential to promote learning. Even when the environment is adequate to a child's development, as in the free play condition, the lack of instruction might be an important determinant for children not showing their full learning potential nor achieving more proficient performance.

The frequency of the activities might explain the difference in results between the guided play and control groups; however, when comparing the results of the free play in enriched environment group, which also had opportunities to practice four times per week, we see that the frequency of the activities alone did not change the children's motor performance. Without the teacher's instructions, the children in the free play in enriched environment group were not able to take full advantage of the opportunities created in the setting to maximize learning and improve performance. These children showed similar performance to that of the children in the control group, who did not participate in any intervention.

Skills acquisition is the result of the interaction among children's personal characteristics, adequacy of the environment, and adaptation of the tasks to their skill levels (Newell, 1986). In the present study, different strategies were used to positively influence motor performance of the children in the guided play group. Even though the children in the two experimental groups have had similar opportunities to practice - concerning the use of equipment and appropriate facilities - as well as protected for safety issues, the teacher's role was essential for children to make progress. The adequacy of the activities to children's individual characteristics, the consequent higher success chances, the variety of experiences as new challenges, the verbal instructions, feedback, demonstrations and encouragement seem to have an important impact on the children's motor performance in the guided play group. Our results agree with results from other studies herein mentioned, and require us to reflect about the need to combine the play and everyday free activities of young children with quality physical education programs. These programs should establish objectives, appropriate content, organization, implementation of methodological strategies that favor progress for children, together with a careful evaluation of the teaching-learning process. In this scenario, the physical education teacher may be the key element for children to develop their full potential.

Looking closely at gender comparisons, previous studies report better motor performance for boys, especially in object-control skills (Beurden et al., 2002; Booth et al., 1999; Goodway \& Rudisill, 1997; Hume et al., 2008; Valentini \& Rudisill, 2004a; 2004b). This tendency is also well discussed in literature (Gabbard, 2011; Gallahue et al., 2011; Haywood \& Getchell, 2009; Payne \& Isaacs; 2008). Nevertheless, in the present study, kindergarten girls demonstrated better locomotor skill performance both in pre- and post-test; whereas, for object-control skills, performance was similar for girls and boys. Although girls scored higher in the pre-test locomotor skills, overall gross motor performance was similar in the pre-test for boys and girls. On the contrary, in the post-test, the girls' superior locomotor performance had a positive impact on the gross motor quotient scores. To date, only one study showed similar results. Ojala and Talts (2007) compared preschoolers' physical and motor development, in Finland and Estonia, and found superior performance for girls. In fact, in Estonia, girls were better than boys in eight out of the nine assessed areas 
(learning to learn skills, social skills, language and interaction, ethics, science and environment, health, physical and motor development, and art and culture)_except mathematics. In Finland, girls were better than boys in six out of the nine assessed areas - except language, mathematics, and science. The authors suggest that, in kindergarten, almost all teachers are women, and they understand better how to teach girls and how the girls tend to learn.

Regarding locomotor skills, Goodway and Rudisill (1997) and Goodway et al. (2003) reported similar performance for boys and girls. The results of the present study do not enable us to confirm or refute the effect of gender on motor development, considering the inconclusive results found in the present investigation and in many other studies approaching this topic. As observed by Marshall and Bouffard (1997), there is still a need for studies concerning younger children's locomotor skills and gender. However, it is important to notice that the intervention studies on motor performance considering gender in the statistical design have shown similar locomotor gains over time among boys and girls (Valentini \& Rudisill, 2004a; 2004b).

In the present study, overall results for gender comparisons were distinctive. Both boys and girls in the free play in enriched environment and control groups maintained their performance levels during the intervention. However, boys in the guided play group showed positive changes in locomotor and objectcontrol performance over this period. Girls in the same group, in turn, improved their object-control performance but their improvement in locomotor skills was not significant. This may be partly explained by the fact that, in the pre-test, girls already showed higher results, which leads us to consider that there may be a limit of improvement for individuals who are more skilled right in the beginning of the intervention program. The results reinforced that similar opportunities to learn was offered for boys and girls in the guided play program. Unfortunately, the lack of motor experiences and instruction in the free play in enriched environment and control groups led to stagnation and even decline in the children's motor development.

\section{Final considerations}

The results of the present study strongly reinforced the major importance of planning the physical education curriculum for kindergarten aiming at children's engagement in pleasant activities and valuable experiences. In the first years of school, children need to experience the joy of free play, but also the teachers' instruction in guided play. Combining free and guided play with motor skill tasks planned by teacher in order to meet children's needs is an interesting strategy to help them accomplish their full motor potential. Also, this strategy reinforces the teacher's essential role in the developmental process.

\section{References}

Barela, J.A. (2013). Fundamental motor skill proficiency is necessary for children's motor activity inclusion. Motriz, 19(3), 548-551. Berry, J., Poortinga, Y., Segall, M., \& Dasen, P. (1992). Cross-cultural psychology: Research and applications. Cambridge: Cambridge University Press.

Beurden, E., Zask, A., Barnett, L., \& Dietrich, U. (2002). Fundamental Movement Skills - How Do Primary Scholl Children Perform? The 'Move it Groove it' Program in Rural Australia. Journal of Science and Medicine in Sport, 5(3), 244-252.

Booth, M., Okely, T., McLellan, L., Phongsavan, P., Macaskill, P., Patterson, J., Wright, J., \& Holland, B. (1999). Mastery of Fundamental Motor Skills among New South Wales School Students: Prevalence and Sociodemographic Distribution. Journal of Science and Medicine in Sport, 2(2), 93-105.

Bronfenbrenner, U. (1979). The ecology of human development: experiments by nature and design. Cambridge: Harvard University Press.

Connor-Kuntz, F., \& Dummer, G. (1996). Teaching across the curriculum: Language-enriched physical education for preschool children. Adapted Physical Activity Quarterly, 13(3), 302-315.

Cotrim, J., Lemos, A., Néri Jr., J., \& Barela, J.A. (2011) Desenvolvimento de habilidades motoras fundamentais em crianças com diferentes contextos escolares. Revista da Educação Física/UEM, 22(4), 523-533.

Council on Physical Education for Children [COPEC]. (1992). Developmentally appropriate physical education practices for children: A position statement of the Council on Physical Education for Children. Reston, VA: National Association for Sport and Physical Education.

Gabbard, C. (2011). Lifelong motor development. 6ed. San Francisco: Pearson Education.

Gallahue, D., Ozmun, J., \& Goodway, J. (2011). Understanding motor development: infants, children, adolescents, adults ( $\left.7^{\text {th }} \mathrm{ed}\right)$. Boston: McGraw- Hill.

Gallahue, D., \& Donnelly, F. (2003). Developmental Physical Education for All Children ( $4^{\text {th }}$ ed). Champaign: Human Kinetics.

Goodway, J., \& Branta, C. (2003). Influence of a motor skill intervention on fundamental motor skill development of disadvantaged preschool children. Research Quarterly for Exercise and Sport, 74(1), 36-46.

Goodway, J., \& Rudisill, M. (1997). Perceived physical competence and actual motor skill competence of African American preschool children. Adapted Physical Activity Quarterly, 14(4), 314-326.

Goodway, J., Crowe, H., \& Ward, P. (2003). Effects of motor skill instruction on fundamental motor skill development. Adapted Physical Activity Quarterly, 20(3), 298-314.

Goodway, J., Rudisill, M., \& Valentini, N. (2002). The influence of instruction on the development of catching in young children. In: J. Clark and J. Humphrey (Eds). Motor development: research and reviews (pp.96-119). NASPE Publication. Reston.

Graham, G. (2008). Teaching children physical education: becoming a master teacher ( $3^{\text {rd }}$ ed). Champaign: Human Kinetics.

Graham, G., Holt-Hale, S., \& Parker, M. (2007). Children moving: a reflective approach to teaching physical education $\left(7^{\text {th }} \mathrm{ed}\right)$. New York: McGraw-Hill Companies.

Haywood, K., \& Getchell, N. (2009). Life Span Motor Development ( $5^{\text {th }}$ ed). Champaign: Human Kinetics.

Hume, C., Okely, A., Bagley, S., Telford, A., Booth, M., Crawford, D., \& Salmon, J. (2008). Does weight status influence associations between children's fundamental movement skills and physical activity? Research Quarterly for Exercise and Sport, 79(2), 158 - 165.

Kirk, D. (2003). Student learning and the social construction of gender in sport and physical education. In: S. Silverman and C. Ennis (Eds). Student Learning in Physical Education: applying research to enhance instruction ( $\left.2^{\text {nd }} \mathrm{ed}\right)$ ( $\mathrm{pp}$ 67-81). Champaign: Human Kinetics.

Lee, A. (2002). Promoting Quality School Physical Education: Exploring the Root of the Problem. Research Quarterly for Exercise and Sport, 73(2),118-124. 
Lemos, A., Avigo, E., \& Barela, J.A. (2012). Physical education in kindergarten promotes fundamental motor skill development. Advances in Physical Education, 2(1), 17-21.

Marshall, J., \& Bouffard, M. (1997). The effects of quality daily physical education on movement competency in obese versus nonobese children. Adapted Physical Activity Quarterly, 14(3), 222-237.

National Association for Sport and Physical Education [NASPE]. (2000). Appropriate Practices in Movement Programs for Young Children Ages 3-5. Reston, VA.

Newell, K. (1986). Constraints on the development of coordination. In: $\mathrm{M}$. Wade and $\mathrm{H}$. Whiting (Eds). Motor development in children: aspects of coordination and control (pp.341-360). Dordrecht: Martins Nijhoff.

Ojala, M., \& Talts, L. (2007). Preschool achievement in Finland and Estonia: cross-cultural comparison between the cities of Helsinki and Tallinn. Scandinavian Journal of Educational Research, 51(2), 205-221.

Okely, A., \& Booth, M. (2004). Mastery of Fundamental Movement Skills among Children in New South Wales: Prevalence and Sociodemographic Distribution. Journal of Science Medicine and Sport, 7(3), 358-372.

Palma, M., Camargo, V., \& Pontes, M. (2012). Efeitos da atividade física sistemática sobre o desenvolvimento motor de crianças pré-escolares. Revista da Educação Física/UEM, 23(3), 421-429.

Payne, V. G., \& Isaacs, L. (2008). Human Motor Development: a lifespan approach $\left(7^{\text {th }} \mathrm{ed}\right)$. New York: McGraw-Hill.

Ramey, C., \& Ramey, S. (1994). Which children benefit the most from early intervention? Pediatrics, 94(6), 1064-1066.

Rink, J. (2003). Effective instruction in physical education. In: S. Silverman and C. Ennis (Eds). Student Learning in Physical Education: applying research to enhance instruction $\left(2^{\text {nd }} \mathrm{ed}\right)(\mathrm{pp} .165$ 186). Champaign: Human Kinetics.

Rodrigues, D., Avigo, E., Leite, M., Bussolin, R., \& Barela, J.A. (2013). Desenvolvimento motor e crescimento somático de crianças com diferentes contextos no ensino infantil. Motriz, 19(3), S49-S56.

Sacha, T., \& Russ, S. (2006). Effects of pretend imagery on learning dance in preschool children. Early Childhood Education Journal, 33(5), 341-345.

Sanders, S. (2002). Active for life: developmentally appropriate movement programs for young children. Washington: National Association for the Education of Young Children.

Seefeldt, V., \& Haubenstricker, J. (1982). Patterns, phases, or stages: An analytical model for the study of developmental movement. In: J. Kelso and J. Clark (Eds.). The development of movement control and co-ordination (pp.309-318). New York: John Wiley \& Sons.

Siedentop, D., \& Tannehill, D. (2000). Developing teaching skills in physical education. 4ed. Mountain View: Mayfield Publishing Company.

Smith, P. (1993). Play and the uses of play. In: J. Moyles (Ed). The excellence of play (pp.15-26). Maidenhead: Open University.

Ulrich, D. (2000). Test of Gross Motor Development - Second Edition. Austin: PRO-ED.

Valentini, N., \& Rudisill, M. (2004a). Motivational Climate, Motor -Skill Development, and Perceived Competence: Two Studies of Developmentally Delayed Kindergarten Children. Journal of Teaching in Physical Education, 23(3), 216-234.

Valentini, N., \& Rudisill, M. (2004b). An inclusive mastery climate intervention and the motor skill development of children with and without disabilities. Adapted Physical Activity Quarterly, 21(4), 330-347.

Vygotsky, L. (1980). Mind in society: the development of higher psychological process. Cambridge: Harvard University Press.

Weiss, M., \& Gill, D. (2005). What goes around comes around: Re-emerging themes in sport and exercise psychology. Research Quarterly for Exercise and Sport, 76(2), 71-87.

\section{Authors' note}

Míriam Stock Palma, Ph D., is affiliated with the Federal University of Rio Grande do Sul. The main focus of her research is the physical education in educational environments. http://lattes.cnpq. br/6947989955632969

Beatriz Oliveira Pereira, Ph D., is a full professor of the University of Minho, Institute of Education, Portugal, and is a member of the Research Centre on Child Studies. http://lattes.cnpq.br/6143064143846471 Nadia Cristina Valentini, Ph D., is affiliated with the Federal University of Rio Grande do Sul. Post-Doctor at School of Public Health, University of Maryland, USA. The main focus of her research is the motor development of children at risk, specifically the ones from families in social economic vulnerability. http://lattes.cnpq.br/3458947518634904

\section{Corresponding author}

Míriam Stock Palma

Rua Chile, 572 ap. 302, Bairro Jardim Botânico, Porto Alegre 90670140 RS, Brazil

Telephones: (51) 93151305; (51) 33431688; (51) 33085870

e-mail: miriam.palma@ufrgs.br

Manuscript received on August 14, 2013

Manuscript accepted on April 26, 2014

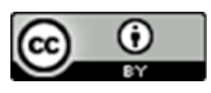

Motriz. The Journal of Physical Education. UNESP. Rio Claro, SP, Brazil - eISSN: 1980-6574 - under a license Creative Commons - Version 3.0 